\title{
Quality and Composition of Airén Wines Fermented by Sequential Inoculation of Lachancea thermotolerans and Saccharomyces cerevisiae
}

\author{
Ángel Benito, Fernando Calderón, Felipe Palomero and Santiago Benito* \\ Department of Chemistry and Food Technology, Polytechnic University of Madrid, \\ Ciudad Universitaria S/N, ES-28040 Madrid, Spain \\ Received: April 19, 2015 \\ Accepted: November 30, 2015
}

\begin{abstract}
Summary
This study evaluates the influence of Lachancea thermotolerans on low-acidity Airén grape must from the south of Spain. For this purpose, combined fermentations with $\mathrm{La}$ chancea thermotolerans and Saccharomyces cerevisiae were compared to a single fermentation by $S$. cerevisiae. Results of all developed analyses showed significant differences in several parameters including acidity, population growth kinetics, concentration of amino acids, volatile and non-volatile compounds, and sensorial parameters. The Airén wine quality increased mainly due to the acidification by L. thermotolerans. The acidification process caused a lactic acid increment of $3.18 \mathrm{~g} / \mathrm{L}$ and a reduction of 0.22 in $\mathrm{pH}$ compared to the control fermentation, performed by S. cerevisiae.
\end{abstract}

Key words: Airén wine, Lachancea thermotolerans, Saccharomyces cerevisiae, L-lactic acid, pyruvic acid, glycerol, ethanol, amino acids, biogenic amines, combined fermentation

\section{Introduction}

In recent years, global climate change has set a trend towards an increase in sugar content and a decrease in the acidity of grape juices. Microbiological acidification can play an essential role in satisfying the growing wine market demand for quality wines.

Traditionally, Saccharomyces cerevisiae is the yeast used widely for winemaking. However, grapes are not sterile media and there are many other yeast species with plenty of potential to solve new oenology challenges that must be studied. Several research groups have studied non-Saccharomyces yeast applications $(1,2)$ in different grape varieties such as Sauvignon blanc $(3,4)$, Chenin blanc (4), Chardonnay (4-6), Amarone (7), Muscat (8), Muscat d'Alexandrie (9), Debina (10), Macabeo $(11,12)$, Folle blanche (13), Bobal (14), Alvarinho, Loureiro, Trajadura, Pedernã, Azal Branco, Avesso (15), Airén $(16,17)$, Pedro Ximenez (18), Sangiovese (19), Pinot noir (20), Emir (21,22), Syrah (23-26), Tempranillo $(27,28)$ and Riesling (29). In most cases improvements in wine quality were reported.
The presence of wild non-Saccharomyces yeasts in fermentations was traditionally associated with high levels of acetic acid and other off-flavours. Nevertheless, nowadays researchers and winemakers are aware of the positive influence of non-Saccharomyces yeasts on wine aroma complexity $(1,2,29-40)$. The development of multistarter fermentation with Saccharomyces cerevisiae as a binding partner has been proposed to overcome the shortcomings of alcoholic fermentation with non-Saccharomyces yeasts. Mixed fermentations are of interest because of some enzymatic properties (glycosidases, $\beta$-lyase, etc.), ethanol reduction and the release of some interesting metabolites such as glycerol, pyruvic acid and mannoproteins, among others (41-44).

Some studies have analysed the use and influence of different non-Saccharomyces species on wine quality. In most cases sequential fermentation was reported to be the best option. These yeast species include Kloeckera apiculata (45), Hanseniaspora uvarum (46), Hanseniaspora vineae (6, 27), Torulospora delbrueckii $(7,28,47)$, Metschnikowia pulcher- 
rima $(3,47,48)$, Candida zemplinina (49), Zygosaccharomyces bailii $(50,51)$, Schizosaccharomyces pombe $(44,52)$, Hansenula anomala (53), Pichia guillermondii (54) and Lachancea thermotolerans $(19,29,55-59)$. Among these species, L. thermotolerans, previously called Kluyveromyces thermotolerans, has been used specifically to increase the acidity of wines, causing increases of L-lactic acid concentration from 0.23 to $9.6 \mathrm{~g} / \mathrm{L}$ depending on the different trial conditions $(19,29,55-59)$.

This study aims to enhance Airén wine quality. This Spanish variety is considered as a neutral and very productive grape but is usually associated with low-quality wine. However, this variety is the most planted in Spain. Most Airén vineyards are located in the centre of the southern Spain. This area is considered to be a warm semi-desert region, where high sugar contents and lack of acidity in wine are the main problems. Therefore, Lachancea thermotolerans 617 was selected among other non-Saccharomyces yeasts in this study to perform combined fermentations with $S$. cerevisiae in order to increase the acidity and quality of Spanish Airén wine.

\section{Materials and Methods}

\section{Microorganisms}

The following yeast strains were used for the experimental fermentation of the studied Airén must: Saccharomyces cerevisiae 87 (CECT 12512; Spanish Type Culture Collection, Valencia, Spain) and Lachancea thermotolerans 617 (CECT 12672; Spanish Type Culture Collection).

\section{Vinification}

Grapes of Airén cultivar (Vitis vinifera L.), grown in El Socorro experimental vineyard (Madrid, Spain) were used in the fermentations. Using a microvinification method similar to that described in scientific literature (60), $3.9 \mathrm{~L}$ of sterilised must $\left(115^{\circ} \mathrm{C}, 15 \mathrm{~min}\right)$ were placed in 4.9-litre glass fermentation vessels, leaving enough space for the emission of carbon dioxide. No sulphur dioxide was added to any vessel. Sugar concentration was $244.51 \mathrm{~g} / \mathrm{L}$, $\mathrm{pH}=3.68$, primary amino nitrogen (PAN; Biosystems S.A., Barcelona, Spain) $177 \mathrm{mg} / \mathrm{L}$, and lactic and acetic acids below $0.1 \mathrm{~g} / \mathrm{L}$. A concentration of $0.4 \mathrm{~g} / \mathrm{L}$ of Actimax Natura (Agrovin S.A., Alcázar de San Juan, Spain), inactivated autolyzed yeasts naturally rich in amino acids, was added to provide nutrition for the media.

Three assays were performed (all in triplicate): (i) inoculation of the must with S. cerevisiae 87 alone (SC; 100 $\mathrm{mL}$ containing $1.18 \cdot 10^{7} \mathrm{CFU} / \mathrm{mL}$ ), (ii) inoculation with $S$. cerevisiae $87\left(1.18 \cdot 10^{7} \mathrm{CFU} / \mathrm{mL}\right)$ and L. thermotolerans 617 (100 mL containing 2.95 $10^{7} \mathrm{CFU} / \mathrm{mL}$ ) together (mixed fermentation: $\mathrm{LT} \times \mathrm{SC}$ ), and (iii) inoculation with L. thermotol-

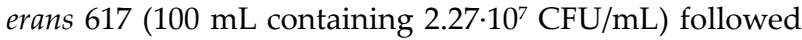
by S. cerevisiae 87 (100 mL containing $\left.10^{7} \mathrm{CFU} / \mathrm{mL}\right) 96 \mathrm{~h}$ later (sequential fermentation: LT...SC). Yeast inocula were produced using $100 \mathrm{~mL}$ of sterilised must with $1 \mathrm{~mL}$ of yeast extract peptone dextrose (YEPD; Pronadisa, Madrid, Spain) liquid medium (61), in the concentration of $10^{6} \mathrm{CFU} / \mathrm{mL}$ (determined using a counting chamber). To reach this population, $100 \mu \mathrm{L}$ of each yeast suspension were cultivated in $10 \mathrm{~mL}$ of YEPD at $25^{\circ} \mathrm{C}$ for $24 \mathrm{~h}$. This procedure was repeated successively three times before the final inoculation of $1 \mathrm{~mL}$ of the suspension. All inocula were prepared in 250-mL flasks filled with $98 \% \mathrm{H}_{2} \mathrm{SO}_{4}$ (Panreac, Barcelona, Spain), which allowed the release of $\mathrm{CO}_{2}$ while avoiding microbial contamination (62), and sealed with a 14-cm Muller valve (Alamo, Madrid, Spain). The temperature was maintained at $25^{\circ} \mathrm{C}$ for $48 \mathrm{~h}$. The development of inocula proceeded without aeration, oxygen injection or agitation. All fermentation processes, which were done in triplicate, were carried out at $25^{\circ} \mathrm{C}$. When the sugar concentration fell below $3 \mathrm{~g} / \mathrm{L}$, the wines were racked and stabilised for 7 days at $4{ }^{\circ} \mathrm{C}$. The wine was then bottled, and a concentration of $40 \mathrm{mg} / \mathrm{L}$ of sulphur dioxide in the form of potassium disulfite was added. Sealed bottles were placed horizontally in a climate chamber at $4{ }^{\circ} \mathrm{C}$ for three weeks until the sensory evaluation.

\section{Analytical determinations of non-volatile compounds}

Glucose and fructose, L-lactic acid, acetic acid, glycerol, pyruvic acid, acetaldehyde, L-malic acid and primary amino nitrogen were all determined using a Y15 enzymatic autoanalyzer (Biosystems S.A.) with corresponding kits. Ethanol, $\mathrm{pH}$, free $\mathrm{SO}_{2}$ and total $\mathrm{SO}_{2}$ profile were determined following the methods described in the Compendium of International Methods of Analysis of Wines and Musts (63).

\section{Growth kinetics during microvinification}

During fermentations, aliquots were taken periodically under aseptic conditions and further tenfold dilutions were made serially. Growth kinetics was monitored by plating $100 \mu \mathrm{L}$ of the appropriate dilution on lysine medium (Oxoid, Basingstoke, UK) for counting non-Saccharomyces yeasts (64) and YEPD medium (Pronadisa) for total yeast counts (61). Colonies were counted after growth at $30^{\circ} \mathrm{C}$ for $48-72 \mathrm{~h}$.

\section{Analytical determination of volatile compounds}

The concentration of volatile compounds, all of which influence wine quality, was measured at the end of alcoholic fermentation by gas chromatography using an Agilent Technologies 6850 gas chromatograph with a flame ionisation detector (Hewlett Packard, Palo Alto, CA, USA) (65), calibrated with 4-methyl-2-pentanol (Fluka, Sigma-Aldrich Corp., Buchs, Switzerland) as an internal standard. Gas chromatography standards (Fluka, Sigma-Aldrich Corp.) were used to provide standard patterns. Higher alcohols were separated according to the Compendium of International Methods of Analysis of Wines and Musts (63), with the detection limit of $0.1 \mathrm{mg} / \mathrm{L}$. Minor compounds were quantified using gas chromatography-mass spectrometry as described by Lopez et al. (66) with the modifications introduced by Loscos et al. (67).

\section{Analytical determination of amino acids}

The amino acids were analysed using a Jasco (Tokyo, Japan) ultra-high-performance liquid chromatograph (UHPLC) series X-LCTM, equipped with a fluorescence detector 3120-FP. Gradients of solvent A (methanol/acetonitrile 50:50, by volume) and B (sodium acetate/tetrahydrofuran 99:1, by volume) were used in a $\mathrm{C} 18\left(\mathrm{HALO}^{\circledR}\right.$, Wilming- 
ton, DE, USA) column (100 $\mathrm{mm} \times 2.1 \mathrm{~mm}$; particle size 2.7 $\mu \mathrm{m})$ as follows: $90 \% \mathrm{~B}$ at $0.25 \mathrm{~mL} / \mathrm{min}$, from 0 to $6 \mathrm{~min}$; 90-78 \% linear gradient $\mathrm{B}$ at $0.2 \mathrm{~mL} / \mathrm{min}$, from 6 to 7.5 $\min ; 78 \% \mathrm{~B}$ from 7.5 to $8 \mathrm{~min}, 78-74 \%$ linear gradient $\mathrm{B}$ at $0.2 \mathrm{~mL} / \mathrm{min}$, from 8 to $8.5 \mathrm{~min}, 74 \% \mathrm{~B}$ at $0.2 \mathrm{~mL} / \mathrm{min}$, from 8.5 to $11 \mathrm{~min}, 74-50 \%$ linear gradient $\mathrm{B}$ at $0.2 \mathrm{~mL} / \mathrm{min}$, from 11 to $15 \mathrm{~min}, 50 \% \mathrm{~B}$ at $0.2 \mathrm{~mL} / \mathrm{min}$, from 15 to 17 $\mathrm{min}, 50-20 \%$ linear gradient $\mathrm{B}$ at $0.2 \mathrm{~mL} / \mathrm{min}$, from 17 to $21 \mathrm{~min}, 20-90 \%$ linear gradient $\mathrm{B}$ at $0.2 \mathrm{~mL} / \mathrm{min}$, from 21 to $25 \mathrm{~min}$ and re-equilibration of the column from 25 to 26 min to the initial gradient conditions. The scanning range for the detection of amino acids was 340-455 nm. Amino acids were quantified by comparison against their external standards, and different acids were identified by their retention times.

\section{Analytical determination of biogenic amines}

The biogenic amines were analysed using a Jasco UHPLC chromatograph series X-LCTM, equipped with a fluorescence detector 3120-FP. Gradients of solvent A (methanol/acetonitrile, 50:50, by volume) and B (sodium acetate/tetrahydrofuran, 99:1, by volume) were used in a C18 $\left(\right.$ HALO $\left.^{\circledR}\right)$ column $(100 \mathrm{~mm} \times 2.1 \mathrm{~mm}$; particle size 2.7 $\mu \mathrm{m}$ ) as follows: $60 \% \mathrm{~B}$ at $0.25 \mathrm{~mL} / \mathrm{min}$, from 0 to $5 \mathrm{~min}$; 60-50\% linear gradient $\mathrm{B}$ at $0.25 \mathrm{~mL} / \mathrm{min}$, from 5 to $8 \mathrm{~min}$; $50 \%$ B from 8 to $9 \mathrm{~min}, 50-20 \%$ linear gradient B at 0.2 $\mathrm{mL} / \mathrm{min}$, from 9 to $12 \mathrm{~min}, 20 \% \mathrm{~B}$ at $0.2 \mathrm{~mL} / \mathrm{min}$, from 12 to $13 \mathrm{~min}, 20-60 \%$ linear gradient $\mathrm{B}$ at $0.2 \mathrm{~mL} / \mathrm{min}$, from 13 to $14.5 \mathrm{~min}$, and re-equilibration of the column from 14.5 to $17 \mathrm{~min}$ to the initial gradient conditions. The scanning range for the detection of biogenic amines was 340 $420 \mathrm{~nm}$. Biogenic amines were quantified by comparison against their external standards, and different amines were identified by their retention times.

\section{Sensory analysis}

The obtained wines were assessed using a blind test by a panel of 15 experienced wine tasters, all staff members of the Chemistry and Food Technology Department of the Polytechnic University of Madrid (Madrid, Spain) and the Accredited Oenology Laboratory of Haro (Haro, Spain). Following consistent terminology by consensus, five aromas and five taste attributes were chosen to describe the wines. The panellists used an unstructured scale, with scores ranging from 0 (no character) to 6 (very strong character), to rate the intensity of the 11 attributes.

\section{Statistical analysis}

PC Statgraphics v. 5 software (Graphics Software Systems, Rockville, MD, USA) was used for statistical analyses. The significance was set to $\mathrm{p}<0.05$ for the ANOVA matrix $F$ value. The mean values were compared using multiple range test.

\section{Results and Discussion}

\section{Fermentation kinetics of the yeast population}

Fig. 1 shows the development of different yeast strains during fermentation. Fermentation time varied
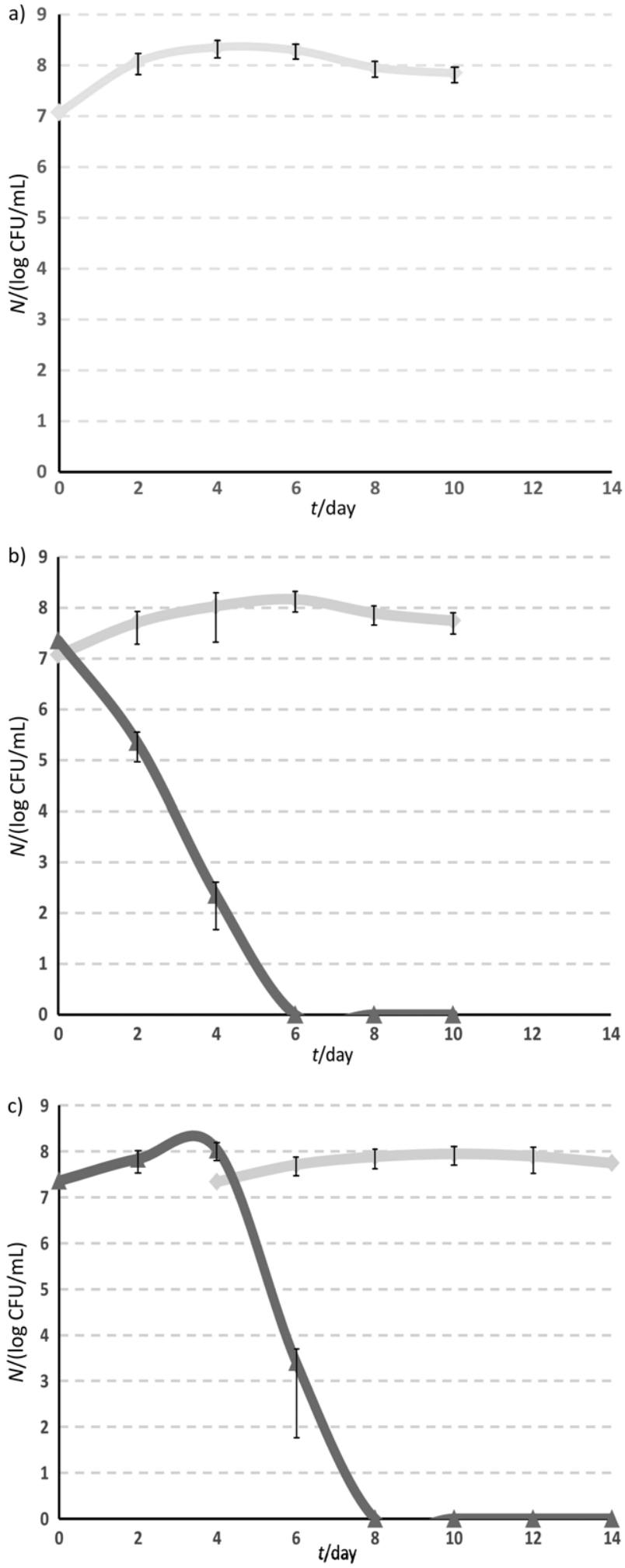

Fig. 1. Yeast cell counts during: a) fermentation with Saccharomyces cerevisiae 87 alone $(\mathrm{SC} ;-), \mathrm{b})$ mixed fermentation with Lachancea thermotolerans $617(\rightarrow)$ and S. cerevisiae $87(\mathrm{LT} \times \mathrm{SC})$, and c) sequential fermentation with L. thermotolerans 617 followed by S. cerevisiae 87 (LT...SC)

from 10 to 14 days. In all mixed fermentations (LT $\times \mathrm{SC}$ or LT...SC) when Saccharomyces cerevisiae 87 was inoculated, 
the number of $L$. thermotolerans 617 cells started to decline fast. Other authors reported previously fermentation kinetics of other non-Saccharomyces strains, in which the presence of non-Saccharomyces strains was also observed during the early stages of fermentation. In this trial $L$. thermotolerans 617 strain disappeared on day 8 in the sequential (LT...SC) fermentation (Fig. 1). This can be explained by the higher fermentation activity of this species compared to other low-fermenting non-Saccharomyces strains. Some S. cerevisiae strains were also reported to secrete antimicrobial peptides that inhibit non-Saccharomyes yeast growth (68). This could explain the early disappearance of $L$. thermotolerans once $S$. cerevisiae was inoculated, even though it has been reported to tolerate up to $9 \%$ (by volume) of ethanol when it ferments on its own (55). In this trial, the LT...SC fermentation was the best option. In the case of the LT $\times$ SC fermentation, L. thermotolerans disappeared fast so acidification was not completed. Cell flocculation or loss of viability can explain the observed reduction in cell numbers during fermentation.

\section{Sugar consumption kinetics and alcohol production}

The Saccharomyces cerevisiae 87 fermenting on its own (SC) and in the LT $\times$ SC fermentation consumed the sugar the fastest (Fig. 2). Fermentation time varied from 10 to 14 days and final alcohol content varied from 13.91 to 14.36 $\%$ (by volume). The ethanol content was lower in the LT... SC fermentation (Table 1). The sugar consumption results analysed in this work (Fig. 2) are in agreement with the lower fermentation activity of Lachancea spp. compared with $S$. cerevisiae (55), due to the fact that in the last stages of fermentation only S. cerevisiae was detected. Several authors question the usefulness of non-Saccharomyces yeast in the production of lower volume fractions of alcohol in wines $(43,69)$. These previous results are in agreement with the lower final alcohol content of the wines produced in the sequential fermentations involving Lachancea thermotolerans 617 (Table 1). However, in our case the alcohol reduction was about $0.4 \%$ (Table 1 ).

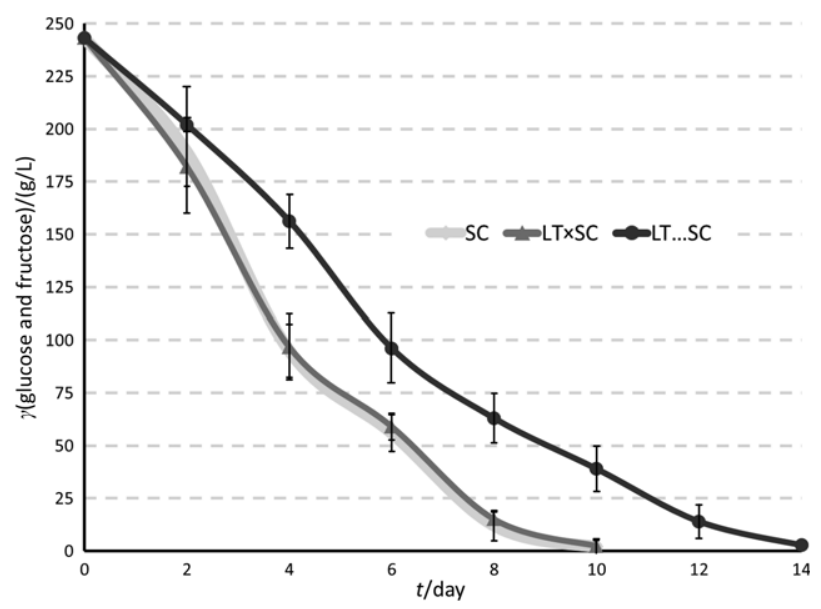

Fig. 2. Change in the glucose and fructose concentration in the studied Airén wines during fermentation with Saccharomyces cerevisiae 87 alone (SC), mixed fermentation with Lachancea thermotolerans 617 and S. cerevisiae $87(\mathrm{LT} \times \mathrm{SC})$, and sequential fermentation with L. thermotolerans 617 followed by S. cerevisiae 87 (LT...SC)
Table 1. Analytical results for the wines produced by different fermentations

\begin{tabular}{|c|c|c|c|}
\hline Compound & SC & $\mathrm{LT} \times \mathrm{SC}$ & LT...SC \\
\hline$\gamma($ L-lactic acid $) /(\mathrm{g} / \mathrm{L})$ & $(0.02 \pm 0.01)^{\mathrm{a}}$ & $(0.24 \pm 0.04)^{\mathrm{b}}$ & $(3.18 \pm 0.19)^{c}$ \\
\hline$\gamma(\mathrm{L}-\mathrm{malic}$ acid $) /(\mathrm{g} / \mathrm{L})$ & $(0.98 \pm 0.02)^{\mathrm{a}}$ & $(1.02 \pm 0.03)^{\mathrm{ab}}$ & $(1.04 \pm 0.03)^{\mathrm{b}}$ \\
\hline$\gamma($ acetic acid $) /(\mathrm{g} / \mathrm{L})$ & $(0.38 \pm 0.02)^{\mathrm{a}}$ & $(0.39 \pm 0.02)^{\mathrm{a}}$ & $(0.31 \pm 0.03)^{\mathrm{b}}$ \\
\hline$\gamma($ glucose + fructose $) /(\mathrm{g} / \mathrm{L})$ & $(1.88 \pm 0.42)^{a}$ & $(2.32 \pm 0.48)^{\mathrm{a}}$ & $(2.77 \pm 0.56)^{\mathrm{a}}$ \\
\hline$\gamma($ glycerol $) /(\mathrm{g} / \mathrm{L})$ & $(7.11 \pm 0.05)^{\mathrm{a}}$ & $(7.18 \pm 0.08)^{\mathrm{a}}$ & $(7.55 \pm 0.16)^{b}$ \\
\hline$\gamma\left(\right.$ free $\left.\mathrm{SO}_{2}\right) /(\mathrm{mg} / \mathrm{L})$ & $(21.12 \pm 2.72)^{\mathrm{a}}$ & $(19.99 \pm 3.26)^{\mathrm{a}}$ & $(17.82 \pm 3.42)^{\mathrm{a}}$ \\
\hline$\gamma\left(\right.$ total $\mathrm{SO}_{2} /(\mathrm{mg} / \mathrm{L})$ & $(48.11 \pm 1.12)^{a}$ & $(46.28 \pm 2.46)^{\mathrm{a}}$ & $(41.32 \pm 2.21)^{\mathrm{b}}$ \\
\hline$\varphi($ alcohol $) \%$ & $(14.36 \pm 0.02)^{\mathrm{a}}$ & $(14.29 \pm 0.04)^{\mathrm{a}}$ & $(13.91 \pm 0.08)^{b}$ \\
\hline$\gamma($ acetaldehyde $) /(\mathrm{mg} / \mathrm{L})$ & $(39.00 \pm 3.02)^{\mathrm{a}}$ & $(35.00 \pm 2.01)^{\mathrm{b}}$ & $(27.00 \pm 4.02)^{\mathrm{c}}$ \\
\hline $\mathrm{pH}$ & $(3.74 \pm 0.01)^{\mathrm{a}}$ & $(3.71 \pm 0.02)^{\mathrm{a}}$ & $(3.52 \pm 0.06)^{b}$ \\
\hline
\end{tabular}

Results represent the mean value \pm S.D. of three replicates. Mean values in the same row with the same letter are not significantly different $(\mathrm{p}<0.05)$

$\mathrm{SC}=$ fermentation with Saccharomyces cerevisiae 87 alone, $\mathrm{LT} \times \mathrm{SC}=$ mixed fermentation with Lachancea thermotolerans 617 and $S$. cerevisiae $87, \mathrm{LT}$...SC=sequential fermentation with $L$. thermotolerans 617 followed by S. cerevisiae 87

\section{Acetic acid metabolism}

Fig. 3 shows the kinetics of acetic acid release. Acetic acid concentration varied from 0.31 to $0.39 \mathrm{~g} / \mathrm{L}$ (Table 1 ). LT...SC fermentation produced the lowest final acetic acid concentration. SC and LT $\times$ SC fermentations had similar final acetic acid content of about $0.38 \mathrm{~g} / \mathrm{L}$ (Fig. 3). One of the problems raised by winemakers is the excessive increase of acetic acid in wines with high presence of non-Saccharomyces yeasts (1). However, previous experiments with $L$. thermotolerans reported significant reduction in final volatile acidity in sequential fermentations of 0.25 (19), 0.06 (56), 0.2 (42) and $0.08 \mathrm{~g} / \mathrm{L}$ (70). Our results confirm an additional decrease in this compound related to the presence of L. thermotolerans (Fig. 3; Table 1). Never-

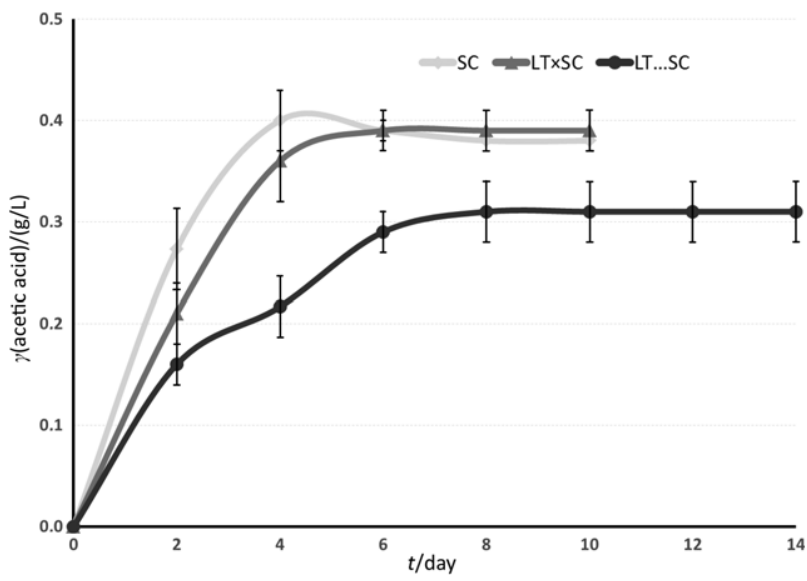

Fig. 3. Change in acetic acid concentration in the studied Airén wines during fermentation with S. cerevisiae 87 alone (SC), simultaneous fermentation with Lachancea thermotolerans 617 and $S$. cerevisiae $87(\mathrm{LT} \times \mathrm{SC})$, and sequential fermentation with L. thermotolerans 617 followed by S. cerevisiae 87 (LT...SC) 
theless, acetic acid concentration in all fermentations was not excessive and it did not affect wine quality negatively. The results show that a controlled use of $L$. thermotolerans in sequential fermentations can cause a decrease of acetic acid production.

\section{L-lactic acid metabolism}

Fig. 4 reports that only the fermentations involving Lachancea thermotolerans 617 produced L-lactic acid. The results varied from $0.24 \mathrm{~g} / \mathrm{L}$ in $\mathrm{LT} \times \mathrm{SC}$ to $3.18 \mathrm{~g} / \mathrm{L}$ in $\mathrm{LT}$...SC (Table 1). Other authors obtained significant acidifications using combined microbiological cultures of L. thermotolerans and S. cerevisiae with the main objective of acidifying musts that were low in titratable acidity. Previously obtained values such as $3.42 \mathrm{~g} / \mathrm{L}$ (19) were similar to the ones reported in this work. In other cases, acidification was higher; up to $5.13 \mathrm{~g} / \mathrm{L}$ (56) has been reported depending on different trial conditions. The production of L-lactic acid is linked to the viable cell content (70). LT...SC fermentation proved to be the best option for acidifying wine in this study (Fig. 4; Table 1). In the case of LT $\times$ SC fermentation, the acidification was significantly lower due to the fast Saccharomyces growth, which impeded a higher acidification by L. thermotolerans.

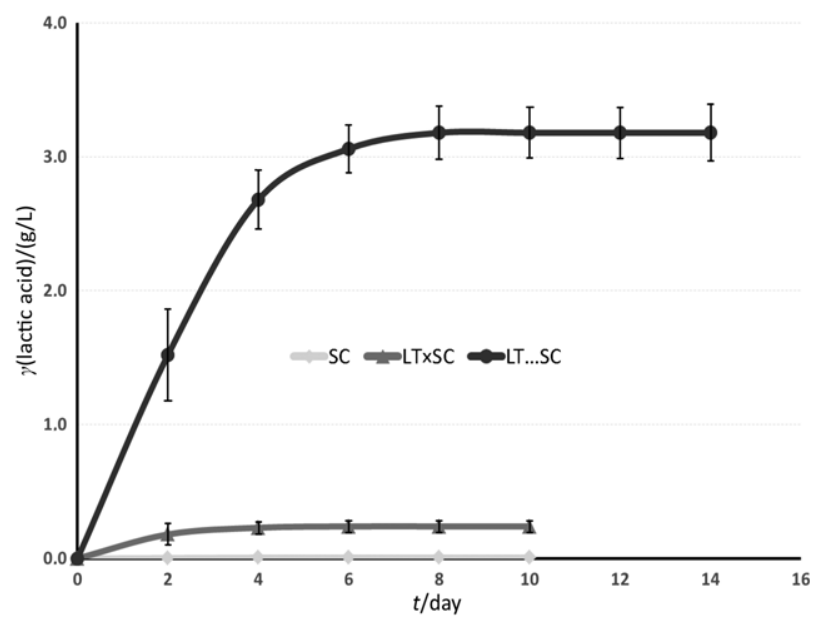

Fig. 4. Change in L-lactic acid concentration in the studied Airén wines during fermentation with Saccharomyces cerevisiae 87 alone (SC), mixed fermentation with Lachancea thermotolerans 617 and S. cerevisiae $87(\mathrm{LT} \times \mathrm{SC})$, and sequential fermentation with L. thermotolerans 617 followed by S. cerevisiae 87 (LT...SC)

\section{L-malic acid metabolism}

Only the final malic acid content in the SC fermentation was lower than in the other fermentations (Table 1); the maximum malic acid reduction rates of $17.65 \%$ in SC, $14.29 \%$ in LT $\times$ SC and $9.25 \%$ in LT...SC fermentation from the initial concentration of $1.19 \mathrm{~g} / \mathrm{L}$ were detected. The slight decrease in malic acid content observed in the fermentations (Table 1) is in agreement with other authors who confirmed that malic acid can be metabolised by several yeast species $(44,52,57)$ at levels lower than $20 \%$, unless Schizosaccharomyces genus is involved.

\section{Glycerol production}

The glycerol content in LT...SC fermentation was higher than those observed in SC and LT $\times$ SC fermentations (Table 1). Final levels of glycerol varied from 7.11 to $7.55 \mathrm{~g} / \mathrm{L}$ (Table 1). Increased glycerol content is described as one of the main contributions of non-Saccharomyces strains to wine quality (71) because it contributes positively to the mouthfeel. L. thermotolerans has been described before in literature as a higher glycerol producer than S. cerevisiae, reporting increases of about 0.69 (19) and $0.93 \mathrm{~g} / \mathrm{L}$ (56). However, some authors have reported that an increase in glycerol production is usually related to an increase in acetic acid production (72), which can be detrimental to wine quality. Our results confirm that this fact seems to be irrelevant in the case of LT...SC fermentation.

\section{Pyruvic acid production}

Maximum pyruvic acid production was observed between the second and fourth day, reaching 128 and 149 $\mathrm{mg} / \mathrm{L}$, respectively (Fig. 5) during the fermentation of Saccharomyces cerevisiae 87 alone (SC) or LT $\times$ SC fermentation. LT...SC fermentation had higher values with a maximum concentration of pyruvic acid of $172.36 \mathrm{mg} / \mathrm{L}$ on day 6 . Previous studies on the production of pyruvic acid by $S$. cerevisiae strains reported maximum values of 60-132 $\mathrm{mg} / \mathrm{L}$ after 4 days of fermentation (52). Similar values were obtained in the present study in SC and slightly higher in LT $\times \mathrm{SC}$ fermentation (Fig. 5). Nevertheless, the LT...SC fermentation obtained significantly higher levels, but not as high as those described for the genus Schizosaccharomyces (52). The concentrations of pyruvic acid and glycerol could indicate that $L$. thermotolerans possesses a highly active glyceropyruvic pathway (73).

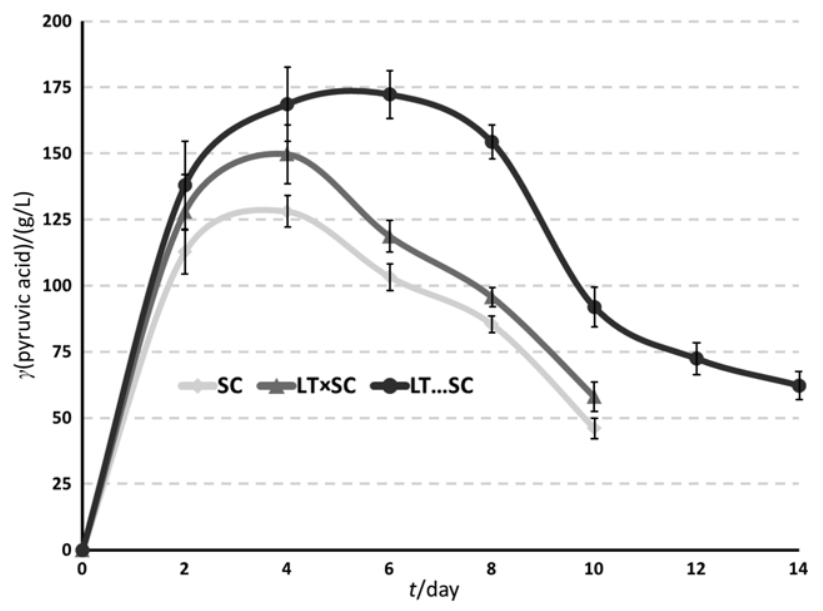

Fig. 5. Change in pyruvic acid concentration in the studied Airén wines during fermentation with $S$. cerevisiae 87 alone (SC), mixed fermentation with Lachancea thermotolerans 617 and $S$. cerevisiae $87(\mathrm{LT} \times \mathrm{SC})$, and sequential fermentation with $L$. thermotolerans 617 followed by S. cerevisiae 87 (LT...SC)

\section{Acetaldehyde production}

The fermentations involving $L$. thermotolerans 617 produced less acetaldehyde, with values that varied from 27 in LT...SC to $35 \mathrm{mg} / \mathrm{L}$ in LTx $\times$ SC (Table 1). SC fermen- 
tation produced more acetaldehyde than the others, with a final concentration of $39.00 \mathrm{mg} / \mathrm{L}$ (Table 1). Acetaldehyde is produced from the yeast metabolism of sugars and it is partly re-utilized (74). Although SC fermentation produced more acetaldehyde than the others (Table 1), all final values were under the sensory threshold of 100-125 $\mathrm{mg} / \mathrm{L}(75)$.

\section{Volatile aroma}

Isoamyl alcohol, ethyl octanoate and isoamyl acetate were formed in higher total concentrations during SC and $\mathrm{LT} \times \mathrm{SC}$ fermentations (Table 2). On the other hand, final concentrations of ethyl lactate, 2-phenylethanol and 2-phenylethyl acetate (Table 2) up to 5.98, 3.92 and 0.16 $\mathrm{mg} / \mathrm{L}$ higher, respectively, were reported in LT...SC than in SC fermentation. Other authors have described non-Saccharomyces yeasts as weaker producers of higher alcohols than Saccharomyces cerevisiae $(10,11,19,46,76)$. LT...DC fermentation produced the most 2-phenylethanol (Table 2 ). Other authors have reported higher production of 2-phenylethanol and ethyl lactate by $L$. thermotolerans than by S. cerevisiae (19), by up to 7.92 and $14.34 \mathrm{mg} / \mathrm{L}$, respectively. L. thermotolerans has also been reported as a weaker ethyl acetate producer than S. cerevisiae (19).

Table 2. Concentrations of volatile compounds detected during different fermentations

\begin{tabular}{lcrr}
\hline$\gamma /(\mathrm{mg} / \mathrm{L})$ & $\mathrm{SC}$ & $\mathrm{LT} \times \mathrm{SC}$ & \multicolumn{1}{c}{ LT ..SC } \\
\hline Hexanol & $(0.96 \pm 0.03)^{\mathrm{a}}$ & $(1.02 \pm 0.04)^{\mathrm{a}}$ & $(0.98 \pm 0.06)^{\mathrm{a}}$ \\
Isoamyl alcohol & $(132.82 \pm 6.06)^{\mathrm{a}}$ & $(126.92 \pm 9.11)^{\mathrm{a}}$ & $(102.43 \pm 10.64)^{\mathrm{b}}$ \\
Isobutanol & $(11.36 \pm 1.28)^{\mathrm{a}}$ & $(12.56 \pm 1.86)^{\mathrm{a}}$ & $(14.42 \pm 2.76)^{\mathrm{a}}$ \\
Ethyl acetate & $(54.42 \pm 3.33)^{\mathrm{a}}$ & $(53.61 \pm 3.42)^{\mathrm{a}}$ & $(50.36 \pm 5.56)^{\mathrm{a}}$ \\
Ethyl decanoate & $(0.11 \pm 0.02)^{\mathrm{a}}$ & $(0.13 \pm 0.03)^{\mathrm{a}}$ & $(0.15 \pm 0.06)^{\mathrm{a}}$ \\
Ethyl hexanoate & $(0.32 \pm 0.02)^{\mathrm{a}}$ & $(0.34 \pm 0.04)^{\mathrm{a}}$ & $(0.29 \pm 0.06)^{\mathrm{a}}$ \\
Ethyl lactate & $(7.16 \pm 0.21)^{\mathrm{a}}$ & $(8.89 \pm 0.48)^{\mathrm{b}}$ & $(13.14 \pm 2.18)^{\mathrm{c}}$ \\
Ethyl octanoate & $(0.36 \pm 0.06)^{\mathrm{a}}$ & $(0.39 \pm 0.09)^{\mathrm{a}}$ & $(0.25 \pm 0.07)^{\mathrm{b}}$ \\
Isoamyl acetate & $(1.62 \pm 0.03)^{\mathrm{a}}$ & $(1.48 \pm 0.06)^{\mathrm{a}}$ & $(0.98 \pm 0.11)^{\mathrm{b}}$ \\
Hexanoic acid & $(8.24 \pm 0.54)^{\mathrm{a}}$ & $(8.32 \pm 0.72)^{\mathrm{a}}$ & $(8.18 \pm 1.16)^{\mathrm{a}}$ \\
Octanoic acid & $(4.32 \pm 0.12)^{\mathrm{a}}$ & $(4.44 \pm 0.18)^{\mathrm{a}}$ & $(3.16 \pm 0.22)^{\mathrm{a}}$ \\
2-Phenylethanol & $(18.16 \pm 0.15)^{\mathrm{a}}$ & $(19.32 \pm 0.82)^{\mathrm{a}}$ & $(22.08 \pm 0.93)^{\mathrm{b}}$ \\
2-Phenylethyl acetate & $(0.36 \pm 0.01)^{\mathrm{a}}$ & $(0.39 \pm 0.03)^{\mathrm{a}}$ & $(0.52 \pm 0.06)^{\mathrm{b}}$ \\
\hline Results represent the & &
\end{tabular}

Results represent the mean value \pm S.D. of three replicates. Mean values in the same row with the same letter are not significantly different $(\mathrm{p}<0.05)$

$\mathrm{SC}=$ fermentation with Saccharomyces cerevisiae 87 alone, $\mathrm{LT} \times \mathrm{SC}=$ mixed fermentation with Lachancea thermotolerans 617 and $S$. cerevisiae $87, \mathrm{LT}$...SC $=$ sequential fermentation with $L$. thermotolerans 617 followed by S. cerevisiae 87

\section{Amino acids and biogenic amines}

Higher final levels of histidine, glycine and leucine were obtained in SC and LT $\times$ SC fermentations than in LT...SC fermentation (Table 3). LT...SC fermentation had higher final levels of alanine, lysine and serine (Table 3). The final concentrations of each biogenic amine were always lower than $1 \mathrm{mg} / \mathrm{L}$ (Table 4). Differences in the amino acid patterns among the different fermentations were
Table 3. Concentrations of amino acids determined after different fermentations

\begin{tabular}{lccr}
\hline$\gamma /(\mathrm{mg} / \mathrm{L})$ & $\mathrm{SC}$ & $\mathrm{LT} \times \mathrm{SC}$ & \multicolumn{1}{c}{ LT ..SC } \\
\hline Histidine & $(6.42 \pm 0.87)^{\mathrm{a}}$ & $(6.79 \pm 1.06)^{\mathrm{a}}$ & $(4.15 \pm 1.21)^{\mathrm{b}}$ \\
Aspartic acid & $(8.62 \pm 1.25)^{\mathrm{a}}$ & $(9.13 \pm 1.60)^{\mathrm{a}}$ & $(10.21 \pm 2.12)^{\mathrm{a}}$ \\
Alanine & $(50.12 \pm 2.58)^{\mathrm{a}}$ & $(52.27 \pm 2.89)^{\mathrm{ab}}$ & $(58.14 \pm 3.12)^{\mathrm{b}}$ \\
Arginine & $(26.06 \pm 1.86)^{\mathrm{a}}$ & $(27.16 \pm 2.52)^{\mathrm{a}}$ & $(29.42 \pm 3.06)^{\mathrm{a}}$ \\
Asparagine & $(29.18 \pm 2.13)^{\mathrm{a}}$ & $(28.42 \pm 2.82)^{\mathrm{a}}$ & $(25.22 \pm 3.16)^{\mathrm{a}}$ \\
Phenylalanine & $(8.52 \pm 0.63)^{\mathrm{a}}$ & $(8.62 \pm 0.89)^{\mathrm{a}}$ & $(8.76 \pm 1.62)^{\mathrm{a}}$ \\
Glycine & $(28.43 \pm 1.08)^{\mathrm{a}}$ & $(27.12 \pm 1.78)^{\mathrm{ab}}$ & $(23.56 \pm 2.22)^{\mathrm{b}}$ \\
Tryptophan & $(0.00 \pm 0.00)^{\mathrm{a}}$ & $(0.00 \pm 0.00)^{\mathrm{a}}$ & $(0.00 \pm 0.00)^{\mathrm{a}}$ \\
Isoleucine & $(2.06 \pm 0.22)^{\mathrm{a}}$ & $(2.18 \pm 0.42)^{\mathrm{a}}$ & $(2.36 \pm 1.11)^{\mathrm{a}}$ \\
Lysine & $(2.42 \pm 0.62)^{\mathrm{a}}$ & $(2.82 \pm 0.86)^{\mathrm{a}}$ & $(6.13 \pm 1.88)^{\mathrm{b}}$ \\
Leucine & $(5.14 \pm 0.42)^{\mathrm{b}}$ & $(4.92 \pm 0.91)^{\mathrm{a}}$ & $(3.11 \pm 0.89)^{\mathrm{b}}$ \\
Ornithine & $(25.17 \pm 0.16)^{\mathrm{a}}$ & $(25.19 \pm 1.06)^{\mathrm{a}}$ & $(23.18 \pm 1.18)^{\mathrm{a}}$ \\
Serine & $(2.28 \pm 0.26)^{\mathrm{a}}$ & $(2.36 \pm 0.76)^{\mathrm{a}}$ & $(4.13 \pm 0.85)^{\mathrm{b}}$ \\
Tyrosine & $(5.36 \pm 0.46)^{\mathrm{a}}$ & $(5.39 \pm 0.68)^{\mathrm{a}}$ & $(6.28 \pm 0.72)^{\mathrm{a}}$ \\
Threonine & $(36.42 \pm 0.18)^{\mathrm{a}}$ & $(35.43 \pm 0.68)^{\mathrm{a}}$ & $(34.21 \pm 1.13)^{\mathrm{a}}$ \\
\hline
\end{tabular}

Results represent the mean value \pm S.D. of three replicates. Mean value in the same row with the same letter are not significantly different $(\mathrm{p}<0.05)$

$\mathrm{SC}=$ fermentation with Saccharomyces cerevisiae 87 alone, $\mathrm{LT} \times \mathrm{SC}=$ mixed fermentation with Lachancea thermotolerans 617 and $S$. cerevisiae $87, \mathrm{LT}$...SC $=$ sequential fermentation with $L$. thermotolerans 617 followed by S. cerevisiae 87

Table 4. Biogenic amine concentration in the studied fermentations

\begin{tabular}{lccc}
\hline$\gamma /(\mathrm{mg} / \mathrm{L})$ & SC & LT×SC & LT...SC \\
\hline Histamine & $(0.37 \pm 0.02)^{\mathrm{a}}$ & $(0.38 \pm 0.03)^{\mathrm{a}}$ & $(0.40 \pm 0.04)^{\mathrm{a}}$ \\
Tyramine & $(0.04 \pm 0.01)^{\mathrm{a}}$ & $(0.03 \pm 0.02)^{\mathrm{a}}$ & $(0.03 \pm 0.02)^{\mathrm{a}}$ \\
Phenylethylamine & n.d. & n.d. & n.d. \\
Putrescine & $(0.76 \pm 0.03)^{\mathrm{a}}$ & $(0.79 \pm 0.04)^{\mathrm{a}}$ & $(0.75 \pm 0.05)^{\mathrm{a}}$ \\
Cadaverine & $(0.22 \pm 0.01)^{\mathrm{a}}$ & $(0.23 \pm 0.02)^{\mathrm{a}}$ & $(0.21 \pm 0.04)^{\mathrm{a}}$ \\
\hline
\end{tabular}

Results represent the mean value $\pm S$.D. of three replicates. Mean values in the same row with the same letter are not significantly different $(\mathrm{p}<0.05)$. n.d.=not detected

$\mathrm{SC}=$ fermentation with Saccharomyces cerevisiae 87 alone, $\mathrm{LT} \times \mathrm{SC}=$ mixed fermentation with Lachancea thermotolerans 617 and $S$. cerevisiae $87, \mathrm{LT}$...SC=sequential fermentation with $L$. thermotolerans 617 followed by S. cerevisiae 87

found, but they could not be related to the aroma of the Airén wines. Different autolysis behaviour might be the reason for this. A histamine value of $2 \mathrm{mg} / \mathrm{L}$ is considered a limiting factor (77) in some countries due to food safety legislation. Our results prove that L. thermotolerans does not produce higher levels of biogenic amines than $S$. cerevisiae. However, most biogenic amines are produced during malolactic fermentation and wine ageing (78). Nevertheless, the lower concentration of histidine (precursor of histamine) found during LT...SC fermentation (Table 3) contributes to reducing the potential risk of histamine formation by bacterial metabolism. Even though no significant differences were found in final biogenic amine contents, other authors have reported reductions of histamine 
of up to $2.2 \mathrm{mg} / \mathrm{L}$ during alcoholic fermentation with the non-Saccharomyces species Hanseniaspora vineae (6).

\section{Sensory evaluation}

Wines produced in LT...SC fermentation trials had better sensorial properties and general acidity (Fig. 6). However, SC and LT...SC fermentations scored highest in sweetness (Fig. 6). This can be easily explained by the elevated L-lactic acid production by L. thermotolerans. Lack of acidity is a common fault described for Spanish Airén grape variety when compared to other European varieties. Although the wines obtained in SC and LT $\times$ SC fermentations were evaluated as sweeter than those in the LT...SC fermentation, all final wines were considered dry from a chemical point of view (Table 1). This perception could be explained due to the different balance between the acidity and sweetness.

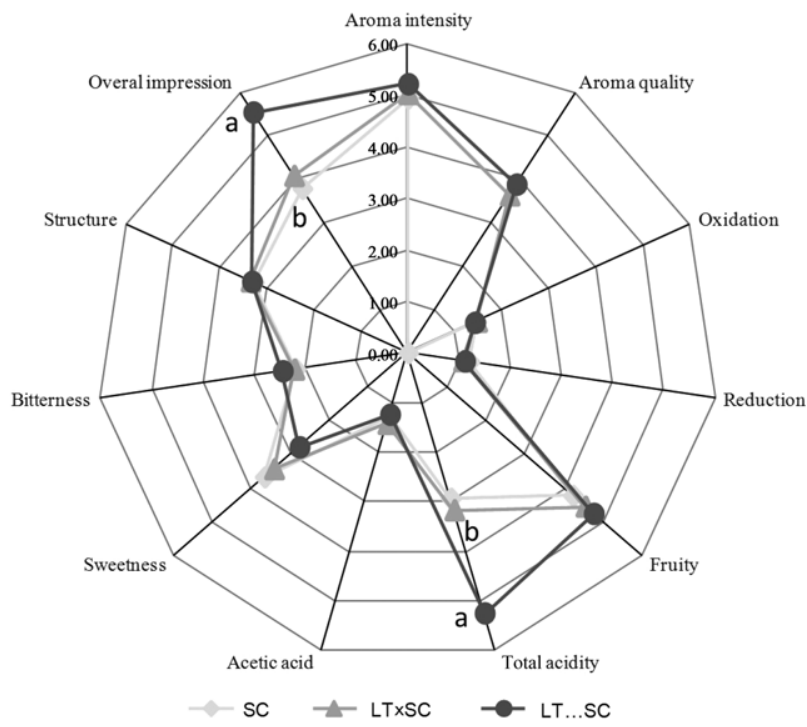

Fig. 6. Taste and olfactory attribute scores for the final wines

\section{Conclusions}

The comparison of the results between the fermentation trials showed differences in several analysed parameters and the positive influence of the studied Lachancea thermotolerans yeast strain on Airén wine quality. Finally, sequential fermentation with $L$. thermotolerans and Saccharomyces cerevisiae remains the best option, as it considerably increased acidity and complexity of the studied neutral grape variety.

\section{Acknowledgements}

The authors are very grateful to EUITA Agricola oenology students for their help in performing the trials during the wine microbiology lessons and to the accredited laboratory Estación Enológica de Haro directors, Montserrat Iñiguez and Elena Meléndez (Haro, Spain) for performing the analyses of volatile aromas, amino acids and biogenic amines.

\section{References}

1. Jolly NP, Varela C, Pretorius IS. Not your ordinary yeast: non-Saccharomyces yeasts in wine production uncovered. FEMS Yeast Res. 2014;14:215-37. http://dx.doi.org/10.1111/1567-1364.12111

2. Ciani M, Comitini F, Mannazzu I, Domizio P. Controlled mixed culture fermentation: a new perspective on the use of non-Saccharomyces yeasts in winemaking. FEMS Yeast Res. 2010;10:123-33. http://dx.doi.org/10.1111/j.1567-1364.2009.00579.x

3. Sadoudi M, Tourdot-Marechal R, Rousseaux S, Steyer D, Gallardo-Chacon JJ, Ballester J, et al. Yeast-yeast interactions revealed by aromatic profile analysis of Sauvignon Blanc wine fermented by single or co-culture of non-Saccharomyces and Saccharomyces yeasts. Food Microbiol. 2012;32: 243-53. http://dx.doi.org/10.1016/j.fm.2012.06.006

4. Jolly NP, Augustyn OPH, Pretorius IS. The effect of non-Saccharomyces yeasts on fermentation and wine quality. S Afr J Enol Vitic. 2003;24:55-62.

5. Soden A, Francis IL, Oakey H, Henschke PA. Effects of co-fermentation with Candida stellata and Saccharomyces cerevisiae on the aroma and composition of Chardonnay wine. Aust J Grape Wine Res. 2000;6:21-30. http://dx.doi.org/10.1111/j.1755-0238.2000.tb00158.x

6. Medina K, Boido E, Fariña L, Gioia O, Gomez ME, Barquet $\mathrm{M}$, et al. Increased flavour diversity of Chardonnay wines by spontaneous fermentation and co-fermentation with Hanseniaspora vineae. Food Chem. 2013;141:2513-21. http://dx.doi.org/10.1016/j.foodchem.2013.04.056

7. Azzolini M, Fedrizzi B, Tosi E, Finato F, Vagnoli P, Scrinzi C, Zapparoli G. Effects of Torulaspora delbrueckii and Saccharomyces cerevisiae mixed cultures on fermentation and aroma of Amarone wine. Eur Food Res Technol. 2012;235:30313. http://dx.doi.org/10.1007/s00217-012-1762-3

8. King A, Dickinson JR. Biotransformation of monoterpene alcohols by Saccharomyces cerevisiae, Torulaspora delbrueckii and Kluyveromyces lactis. Yeast. 2000;16:499-506. http://dx.doi.org/10.1002/(SICI)1097-0061(200004)16:6<499:: AID-YEA548>3.0.CO;2-E

9. Rodríguez ME, Lopes CA, Barbagelata RJ, Barda NB, Caballero AC. Influence of Candida pulcherrima Patagonian strain on alcoholic fermentation behaviour and wine aroma. Int J Food Microbiol. 2010;138:19-25. http://dx.doi.org/10.1016/j.ijfoodmicro.2009.12.025

10. Parapouli M, Hatziloukas E, Drainas C, Perisynakis A. The effect of Debina grapevine indigenous yeast strains of Metschnikowia and Saccharomyces on wine flavour. J Ind Microbiol Biotechnol. 2010;37:85-93. http://dx.doi.org/10.1007/s10295-009-0651-7

11. Clemente-Jimenez JF, Mingorance-Cazorla L, Martínez-Rodríguez S, Las Heras-Vázquez FJ, Rodríguez-Vico F. Molecular characterization and oenological properties of wine yeast isolated during spontaneous fermentation of six varieties of grape must. Food Microbiol. 2004;21:149-55. http://dx.doi.org/10.1016/S0740-0020(03)00063-7

12. Andorrà I, Berradre M, Rozès N, Mas A, Guillamón JM, Esteve-Zarzoso B. Effect of pure and mixed cultures of the main wine yeast species on grape must fermentations. Eur Food Res Technol. 2010;231:215-24. http://dx.doi.org/10.1007/s00217-010-1272-0

13. Rementeria A, Rodriguez JA, Cadaval A, Amenabar R, Muguruza JR, Hernando FL, Sevilla MJ. Yeast associated with spontaneous fermentations of white wines from the 'Txakoli 
de Bizkaia' region (Basque Country, North Spain). Int J Food Microbiol. 2003;86:201-7.

http://dx.doi.org/10.1016/S0168-1605(03)00289-7

14. Viana F, Gil JV, Vallès S, Manzanares P. Increasing the levels of 2-phenylethyl acetate in wine through the use of a mixed culture of Hanseniaspora osmophila and Saccharomyces cerevisiae. Int J Food Microbiol. 2009;135:68-74. http://dx.doi.org/10.1016/j.ijfoodmicro.2009.07.025

15. Moreira N, de Pinho PG, Santos C, Vasconcelos I. Volatile sulphur compounds composition of monovarietal white wines. Food Chem. 2010;123:1198-203.

http://dx.doi.org/10.1016/j.foodchem.2010.05.086

16. Izquierdo-Cañas PM, Palacios García AT, García Romero E. Enhancement of flavour properties in wines using sequential inoculations of non-Saccharomyces (Hansenula and Torulaspora) and Saccharomyces yeast starter. Vitis. 2011;50:177-82.

17. Benito S, Palomero F, Morata A, Calderón F, Palmero D, Suárez-Lepe JA. Physiological features of Schizosaccharomyces pombe of interest in making of white wines. Eur Food Res Technol. 2013;236:29-36. http://dx.doi.org/10.1007/s00217-012-1836-2

18. Peinado RA, Moreno JJ, Maestre O, Mauricio JC. Removing gluconic acid by using different treatments with a Schizosaccharomyces pombe mutant: effect on fermentation byproducts. Food Chem. 2007;104:457-65. http://dx.doi.org/10.1016/j.foodchem.2006.11.070

19. Gobbi M, Comitini F, Domizio P, Romani C, Lencioni L, Mannazzu I, Ciani M. Lachancea thermotolerans and Saccharomyces cerevisiae in simultaneous and sequential cofermentation: a strategy to enhance acidity and improve the overall quality of wine. Food Microbiol. 2013;33:271-81. http://dx.doi.org/10.1016/j.fm.2012.10.004

20. Takush DG, Osborne JP. Impact of yeast on the aroma and flavour of Oregon Pinot Noir wine. Aust J Grape Wine Res. 2012;18:131-7.

http://dx.doi.org/10.1111/j.1755-0238.2012.00181.x

21. Erten $H$, Tanguler $H$. Influence of Williopsis saturnus yeasts in combination with Saccharomyces cerevisiae on wine fermentation. Lett Appl Microbiol. 2010;50:474-9. http://dx.doi.org/10.1111/j.1472-765X.2010.02822.x

22. Tanguler H. Evaluation of Williopsis saturnus inoculum level on fermentation and flavor compounds of white wines made from Emir (Vitis vinifera L.) grown in Anatolia. Food Biotechnol. 2012;26:351-68. http://dx.doi.org/10.1080/08905436.2012.724038

23. Toro ME, Vazquez F. Fermentation behaviour of controlled mixed and sequential cultures of Candida cantarellii and Saccharomyces cerevisiae wine yeasts. World J Microb Biotechnol. 2002;18:347-54. http://dx.doi.org/10.1023/A:1015242818473

24. Morata A, Benito S, Loira I, Palomero F, González MC, Suárez-Lepe JA. Formation of pyranoanthocyanins by Schizosaccharomyces pombe during the fermentation of red must. Int J Food Microbiol. 2012;159:47-53.

http://dx.doi.org/10.1016/j.ijfoodmicro.2012.08.007

25. Benito S, Palomero P, Morata A, Calderón F, Suárez-Lépe JA. New applications for Schizosaccharomyces pombe in the alcoholic fermentation of red wines. Int J Food Sci Tech. 2012; 47:2101-8. http://dx.doi.org/10.1111/j.1365-2621.2012.03076.x

26. Benito S, Palomero P, Gálvez L, Morata A, Calderón F, Palmero D, Suárez-Lepe JA. Quality and composition of red wine fermented with Schizosaccharomyces pombe as sole fermentative yeast, and in mixed and sequential fermentations with Saccharomyces cerevisiae. Food Technol Biotechnol. 2014;52:376-82.

27. Viana F, Belloch C, Vallés S, Manzanares P. Monitoring a mixed starter of Hanseniaspora vineae-Saccharomyces cere- visiae in natural must: Impact on 2-phenylethyl acetate production. Int J Food Microbiol. 2011;151:235-40. http://dx.doi.org/10.1016/j.ijfoodmicro.2011.09.005

28. Belda I, Navascués E, Marquina D, Santos A, Calderon F, Benito S. Dynamic analysis of physiological properties of Torulaspora delbrueckii in wine fermentations and its incidence on wine quality. Appl Microbiol Biotechnol. 2015;99:1911-22. http://dx.doi.org/10.1007/s00253-014-6197-2

29. Benito S, Hofmann T, Laier M, Lochbühler B, Schüttler A, Ebert $\mathrm{K}$, et al. Effect on quality and composition of Riesling wines fermented by sequential inoculation with non-Saccharomyces and Saccharomyces cerevisiae. Eur Food Res Technol. 2015;241:707-17. http://dx.doi.org/10.1007/s00217-015-2497-8

30. Egli CM, Edinger WD, Mitrakul CM, Henick-Kling T. Dynamics of indigenous and inoculated yeast populations and their effect on the sensory character of Riesling and Chardonnay wines. J Appl Microbiol. 1998;85:779-89. http://dx.doi.org/10.1046/j.1365-2672.1998.00521.x

31. Esteve-Zarzoso B, Manzanares P, Ramón D, Querol A. The role of non-Saccharomyces yeasts in industrial winemaking. Int Microbiol. 1998;1:143-8.

32. Fleet GH, Heard GM. Yeast-growth during fermentation. In: Fleet GH, editor. Wine microbiology and biotechnology. Chur, Switzerland: Harwood Academic Publishers; 1993. pp. 27-54.

33. Fleet GH. Yeast interactions and wine flavour. Int J Food Microbiol. 2003;86:11-22. http://dx.doi.org/10.1016/S0168-1605(03)00245-9

34. Fleet GH. Wine yeasts for the future. FEMS Yeast Res. 2008;8:979-95. http://dx.doi.org/10.1111/j.1567-1364.2008.00427.x

35. Gil JV, Mateo JJ, Jiménez M, Pastor A, Huerta T. Aroma compounds in wines as influenced by apiculate yeasts. J Food Sci. 1996;61:1247-50. http://dx.doi.org/10.1111/j.1365-2621.1996.tb10971.x

36. Henick-Kling T, Edinger W, Daniel P, Monk P. Selective effects of sulfur dioxide and yeast starter culture addition on indigenous yeast populations and sensory characteristics of wine. J Appl Microbiol. 1998;84:865-76. http://dx.doi.org/10.1046/j.1365-2672.1998.00423.x

37. Lambrechts MG, Pretorius IS. Yeast and its importance to wine aroma - a review. S Afr J Enol Vitic. 2000;21:97-129.

38. Romano P, Fiore C, Paraggio M, Caruso M, Capece A. Function of yeast species and strains in wine flavour. Int J Food Microbiol. 2003;86:169-80. http://dx.doi.org/10.1016/S0168-1605(03)00290-3

39. Viana F, Gil JV, Genovés S, Vallés S, Manzanares P. Rational selection of non-Saccharomyces wine yeasts for mixed starters based on ester formation and enological traits. Food Microbiol. 2008;25:778-85. http://dx.doi.org/10.1016/j.fm.2008.04.015

40. Carrau F, Gaggero C, Aguilar PS. Yeast diversity and native vigor for flavor phenotypes. Trends Biotechnol. 2015;33:14854 . http://dx.doi.org/10.1016/j.tibtech.2014.12.009

41. Rojas V, Gil JV, Piñaga F, Manzanares P. Studies on acetate ester production by non-Saccharomyces wine yeasts. Int J Food Microbiol. 2001;70:283-9. http://dx.doi.org/10.1016/S0168-1605(01)00552-9

42. Ciani M, Beco L, Comitini F. Fermentation behaviour and metabolic interactions of multistarter wine yeast fermentations. Int J Food Microbiol. 2006;108:239-45. http://dx.doi.org/10.1016/j.ijfoodmicro.2005.11.012

43. Contreras A, Hidalgo C, Henschke PA, Chambers PJ, Curtin C, Varela C. Evaluation of non-Saccharomyces yeasts for the 
reduction of alcohol content in wine. Appl Environ Microb. 2014;80:1670-8. http://dx.doi.org/10.1128/AEM.03780-13

44. Benito S, Palomero P, Calderón F, Palmero D, Suárez-Lepe JA. Schizosaccharomyces. In: Batt CA, Tortorello ML, editors. Encyclopedia of food microbiology. Amsterdam, The Netherlands: Elsevier Ltd, Academic Press; 2014. pp. 365-70.

45. Herraiz T, Reglero G, Herraiz M, Martin-Alvarez PJ, Cabezudo MD. The influence of the yeast and type of culture on the volatile composition of wines fermented without sulfur dioxide. Am J Enol Vitic. 1990;41:313-8.

46. Zironi R, Romano P, Suzzi G, Battistutta F, Comi G. Volatile metabolites produced in wine by mixed and sequential cultures of Hanseniaspora guilliermondii or Kloeckera apiculata and Saccharomyces cerevisiae. Biotechnol Lett. 1993;15: 235-8. http://dx.doi.org/10.1007/BF00128311

47. González-Royo E, Pascual O, Kontoudakis N, Esteruelas M, Esteve-Zarzoso B, Mas A, et al. Oenological consequences of sequential inoculation with non-Saccharomyces yeasts (Torulaspora delbrueckii or Metschnikowia pulcherrima) and Saccharomyces cerevisiae in base wine for sparkling wine production. Eur Food Res Technol. 2015;240:999-1012. http://dx.doi.org/10.1007/s00217-014-2404-8

48. Oro L, Ciani M, Comitini F. Antimicrobial activity of Metschnikowia pulcherrima on wine yeasts. J Appl Microbiol. 2014; 116:1209-17. http://dx.doi.org/10.1111/jam.12446

49. Di Maio S, Genna G, Gandolfo V, Amore G, Ciaccio M, Oliva D. Presence of Candida zemplinina in Sicilian musts and selection of a strain for wine mixed fermentations. S Afr J Enol Vitic. 2012;33:80-7.

50. Domizio P, Romani C, Lencioni L, Comitini F, Gobbi M, Mannazzu I, Ciani M. Outlining a future for non-Saccharomyces yeasts: selection of putative spoilage wine strains to be used in association with Saccharomyces cerevisiae for grape juice fermentation. Int J Food Microbiol. 2011;147:17080. http://dx.doi.org/10.1016/j.ijfoodmicro.2011.03.020

51. Domizio P, Romani C, Comitini F, Gobbi M, Lencioni L Mannazzu I, Ciani M. Potential spoilage non-Saccharomyces yeasts in mixed cultures with Saccharomyces cerevisiae. Ann Microbiol. 2011;61:137-44. http://dx.doi.org/10.1007/s13213-010-0125-1

52. Benito S, Palomero F, Calderón F, Palmero D, Suárez-Lepe JA. Selection of appropriate Schizosaccharomyces strains for winemaking. Food Microbiol. 2014;42:218-24. http://dx.doi.org/10.1016/j.fm.2014.03.014

53. Izquierdo-Cañas PM, García-Romero E, Heras Manso JM, Fernández-González M. Influence of sequential inoculation of Wickerhamomyces anomalus and Saccharomyces cerevisiae in the quality of red wines. Eur Food Res Technol. 2014;239:279-86. http://dx.doi.org/10.1007/s00217-014-2220-1

54. Benito S, Morata A, Palomero F, González MC, Suárez-Lepe JA. Formation of vinylphenolic pyranoanthocyanins by Saccharomyces cerevisiae and Pichia guillermondii in red wines produced following different fermentation strategies. Food Chem. 2011;124:15-23. http://dx.doi.org/10.1016/j.foodchem.2010.05.096

55. Kapsopoulou K, Kapaklis A, Spyropoulos H. Growth and fermentation characteristics of a strain of the wine yeast Kluyveromyces thermotolerans isolated in Greece. World J Microb Biotechnol. 2005;21:1599-602. http://dx.doi.org/10.1007/s11274-005-8220-3

56. Kapsopoulou K, Mourtzini A, Anthoulas M, Nerantzis E. Biological acidification during grape must fermentation using mixed cultures of Kluyveromyces thermotolerans and Saccharomyces cerevisiae. World J Microb Biotechnol. 2007;23:735-9. http://dx.doi.org/10.1007/s11274-006-9283-5

57. Su J, Wang T, Wang Y, Li YY, Li H. The use of lactic acidproducing, malic acid-producing, or malic acid-degrading yeast strains for acidity adjustment in the wine industry. Appl Microbiol Biotechnol. 2014;98:2395-413. http://dx.doi.org/10.1007/s00253-014-5508-y

58. Benito A, Calderón F, Palomero F, Benito S. Combine use of selected Schizosaccharomyces pombe and Lachancea thermotolerans yeast strains as an alternative to the traditional malolactic fermentation in red wine production. Molecules. 2015;20:9510-23.

http://dx.doi.org/10.3390/molecules20069510

59. Mora J, Barbas JI, Mulet A. Growth of yeast species during the fermentation of musts inoculated with Kluyveromyces thermotolerans and Saccharomyces cerevisiae. Am J Enol Vitic. 1990;41:156-9.

60. Sampaio TL, Kennedy A, Vasconcelos MC. Use of microscale fermentations in grape and wine research. Am J Enol Vitic. 2007;58:534-9.

61. Yarrow D. Methods for the isolation, maintenance and identification of yeasts. In: Kurtzman CP, Fell JW, editors. The yeast. A taxonomic study. Amsterdam, The Netherlands: Elsevier Ltd, Academic Press; 1998. pp. 77-100.

62. Vaughnan-Martini A, Martini A. Determination of ethanol production. In: Kurtzman CP, Fell JW, editors. The yeast. A taxonomic study. Amsterdam, The Netherlands: Elsevier Ltd, Academic Press; 1999. p. 107.

63. OIV Official Methods. Compendium of international methods of analysis of wine and must. Paris, France: International Organisation of Vine and Wine, 2015. Available from: http:// www.oiv.int.

64. Morris EO, Eddy AA. Method for the measurement of wild yeast infection in pitching yeast. J Inst Brew. 1957;63:34-5. http://dx.doi.org/10.1002/j.2050-0416.1957.tb02902.x

65. Ortega C, López R, Cacho J, Ferreira V. Fast analysis of important wine volatile compounds: development and validation of a new method based on gas chromatographic-flame ionisation detection analysis of dichloromethane microextracts. J Chromatogr A. 2001;923:205-14. http://dx.doi.org/10.1016/S0021-9673(01)00972-4

66. Lopez R, Aznar M, Cacho J, Ferreira V. Determination of minor and trace volatile compounds in wine by solid-phase extraction and gas chromatography with mass spectrometric detection. J Chromatogr A. 2002;966:167-77. http://dx.doi.org/10.1016/S0021-9673(02)00696-9

67. Loscos N, Hernandez-Orte P, Cacho J, Ferreira V. Release and formation of varietal aroma compounds during alcoholic fermentation from nonfloral grape odorless flavor precursors fractions. J Agric Food Chem. 2007;55:6674-84. http://dx.doi.org/10.1021/jf0702343

68. Albergaria H, Francisco D, Gori K, Arneborg N, Gírio F. Saccharomyces cerevisiae CCMI 885 secretes peptides that inhibit the growth of some non-Saccharomyces wine-related strains. Appl Microbiol Biotechnol. 2010;86:965-72. http://dx.doi.org/10.1007/s00253-009-2409-6

69. Kutyna DR, Varela C, Henschke PA, Chambers PJ, Stanley GA. Microbiological approaches to lowering ethanol concentration in wine. Trends Food Sci Technol. 2010;21:293-302. http://dx.doi.org/10.1016/j.tifs.2010.03.004

70. Comitini F, Gobbi M, Domizio P, Romani C, Lencioni L, Mannazzu I, Ciani M. Selected non-Saccharomyces wine yeast in controlled multistarter fermentations with Saccharomyces cerevisiae. Food Microbiol. 2011;28:873-82. http://dx.doi.org/10.1016/j.fm.2010.12.001 
71. Jolly NP, Augustyn OPH, Pretorius IS. The role and use of non-Saccharomyces yeasts in wine production. S Afr J Enol Vitic. 2006;27:15-39.

72. Prior BA, Toh TH, Jolly N, Baccari C, Mortimer RK. Impact of yeast breeding for elevated glycerol production on fermentation activity and metabolite formation in Chardonnay. S Afr J Enol Vitic. 2000;21:92-9.

73. Ciani M, Maccarelli F. Oenological properties of non-Saccharomyces yeasts associated with winemaking. World J Microb Biotechnol. 1998;14:199-203. http://dx.doi.org/10.1023/A:1008825928354

74. Jackowetz N, Dierschke S, Mira de Orduna R. Multifactorial analysis of acetaldehyde kinetics during alcoholic fermentation by Saccharomyces cerevisiae. Food Res Int. 2011;44:310-6. http://dx.doi.org/10.1016/j.foodres.2010.10.014
75. Zoecklein B, Fugelsang K, Gump B, Nury F, editors. Wine analysis and production. New York, NY, USA: Harwood Academic Publishers; 1995.

76. Romano P, Suzzi G. Higher alcohol and acetoin production by Zygosaccharomyces wine yeasts. J Appl Bacteriol. 1993; 75:541-5. http://dx.doi.org/10.1111/j.1365-2672.1993.tb01592.x

77. Lehtonen P. Determination of amines and amino acids in wine: A review. Am J Enol Vitic. 1996;47:127-33.

78. Alcaide-Hidalgo JM, Moreno-Arribas MV, Martín-Álvarez PJ, Polo MC. Influence of malolactic fermentation, postfermentative treatments and ageing with lees on nitrogen compounds of red wines. Food Chem 2007;103:572-81. http://dx.doi.org/10.1016/j.foodchem.2006.09.002 